\title{
Impact Bruise Resistance Comparison among Peach Cultivars
}

\author{
Niels O. Maness ${ }^{1}$, Gerald H. Brusewitz ${ }^{2}$, and T. Gregory McCollum $^{3}$ \\ Oklahoma Agricultural Experiment Station, Oklahoma State University, \\ Stillwater, OK 74078 \\ Additional index words. Prunus persica, bruise volume, impact testing
}

\begin{abstract}
Impact testing was used to assess the variables related to bruise resistance for four peach [Prunus persica (L.) Batsch] cultivars. The effects of cultivar, ripeness, drop height, and firmness on fruit bruise incidence, bruise volume, respiration, and ethylene evolution rates of freshly harvested peaches were determined. The impact variables peak impact force, contact time, absorbed energy, and percent absorbed energy were measured at three stages of fruit ripeness and at three fruit drop heights. Each of the impact variables changed with fruit ripeness. Cultivars differed in their characteristic response to impact. Fruit impact, under the low to moderate impact energies used, had negligible effects on fruit respiration and ethylene production for the cultivars studied. Bruise incidence and volume increased with drop height and especially with advancing stage of ripeness. Under conditions we used, peach fruit bruise severity could be determined by either bruise incidence in or bruise volume of mesocarp tissue.
\end{abstract}

Bruise damage resulting from impacts during harvesting, packing, handling, and

Received for publication 13 Sept. 1991. Accepted for publication 27 Mar. 1992. This is journal article no. 56035 of the Oklahoma Agricultural Experiment Station. Supported by U.S. Dept. of Agriculture grant 89-34150-4295 and the Oklahoma Agricultural Experiment Station, Oklahoma State University. The cost of publishing this paper was defrayed in part by the payment of page charges. Under postal regulations, this paper therefore must be hereby marked advertisement solely to indicate this fact.

'Dept. of Horticulture and Landscape Architecture

${ }^{2}$ Dept. of Agricultural Engineering.

${ }^{3}$ Dept. of Horticulture and Landscape Architecture. Current address: Agricultural Research Service, U.S. Dept. of Agriculture, 2120 Camden Road, Orlando, FL 32803. transportation is a major cause for fruit rejection by wholesale and retail markets (Brusewitz and Bartsch, 1989). Various instruments have been constructed to understand the bruising process (Brusewitz and Bartsch, 1989; Mohsenin, 1970; Zapp et al., 1990), and impact-damage thresholds have been obtained for selected cultivars of pome fruits (Schulte-Pason et al., 1990). Although differences in bruise potential exist for peach cultivars (Bilanski and Menzies, 1984), formulation of precise impact damage thresholds has been unsuccessful.

Fruit bruising is caused by one or more types of loading: compression, impact, and vibrational (Brusewitz et al., 1991). Compression bruising results from a steady force, such as packing box pressure. Impact bruising results from a sharp, sudden force when fruit falls onto other fruit or onto a hard sur- face. Vibrational bruising results from repetitive impacts, usually of relatively low energy, and is a combination of impact and compression loading. Techniques to apply compression and vibrational loads during bruise resistance testing are time consuming, but impact loads can be applied very quickly and the various physical variables involved can be measured precisely for individual fruit. Many studies have used impact loading for assessment of bruise resistance due to its short testing time, the realistic nature of the procedure, and good correlation with longstanding texture analysis methods. Impactloading procedures have been used to determine peach fruit firmness (Delwiche, 1987), and later an instrument measuring low-energy impacts was adapted for fruit-firmness sorting (Delwiche et al., 1989). Most recently, a device for measuring fruit impacts during transit along a packing line (instrumented sphere) was developed (Brown et al., 1990) and subsequently used to improve design of packing lines to reduce bruising (Sargent et al., 1990; Schulte-Pason et al., 1990).

Table 1. Average mesocarp firmness for four peach cultivars at three stages of ripeness. ${ }^{2}$

\begin{tabular}{lcc}
\hline \hline Cultivar & Ripeness stage $^{\mathrm{y}}$ & Firmness $(\mathrm{N})^{\mathrm{x}}$ \\
\hline Topaz & All & $49.6 \mathrm{a}^{\mathrm{w}}$ \\
Ranger & All & $48.6 \mathrm{a}$ \\
Glohaven & All & $42.2 \mathrm{~b}$ \\
Elberta & All & $34.6 \mathrm{c}$ \\
All & 1 & $54.3 \mathrm{a}$ \\
All & 2 & $44.1 \mathrm{~b}$ \\
All & 3 & $26.2 \mathrm{c}$ \\
\hline
\end{tabular}

${ }^{\mathrm{z}}$ Mesocarp firmness measured using an Effegi penetrometer.

'Ripeness stages were determined based on fixed $\mathrm{L}, \mathrm{a}$, and $\mathrm{b}$ values obtained from the greenest area of fruit: 1 = threshold-mature, $2=$ mature, $3=$ firm ripe.

${ }^{x}$ Means of 30 peaches, with paired readings from each peach.

"Mean separation within columns by LSD, $P=$ 0.05 . 
Table 2. Analysis of variance $\mathrm{F}$ values for the effect of cultivar, ripeness stage, drop height, and fruit mass on various impact variables, bruise incidence, and bruise volume for peaches.

\begin{tabular}{|c|c|c|c|c|c|c|c|}
\hline \multirow[b]{2}{*}{ Variable } & \multirow[b]{2}{*}{$\mathrm{PIF}^{2}$} & \multirow[b]{2}{*}{ PIF : $\mathrm{TPF}^{\mathrm{y}}$} & \multirow[b]{2}{*}{$\begin{array}{l}\text { Contact } \\
\text { time }\end{array}$} & \multicolumn{2}{|c|}{ Absorbed energy } & \multirow[b]{2}{*}{$\begin{array}{c}\text { Bruise } \\
\text { incidence }\end{array}$} & \multirow[b]{2}{*}{$\begin{array}{c}\text { Bruise } \\
\text { vol }\end{array}$} \\
\hline & & & & Total & $\begin{array}{c}\text { Propor- } \\
\text { tional (\%) }\end{array}$ & & \\
\hline Cultivar & $193.0 * *$ & $83.6 * *$ & $41 . .5^{* *}$ & $208.9^{* *}$ & $20.8 * *$ & $9.4^{* *}$ & 1.2 \\
\hline Ripeness stage & 1.7 & $47.7^{*}$ & $230.4^{* *}$ & $568.5^{* *}$ & $52.9 * *$ & 0.05 & $3.7^{*}$ \\
\hline Drop ht & $975.2^{*}$ & $390.1 * *$ & $23.8^{* *} *$ & $965.2^{* *}$ & $66.7 * *$ & $19.3 * *$ & $6.7^{* \prime}$ \\
\hline Fruit mass & $239.1 * *$ & 1.8 & $270.6^{* * *}$ & $753.1^{* *}$ & $15.9 * *$ & 0.03 & $4.1 *$ \\
\hline
\end{tabular}

${ }^{2}$ Peak impact force.

${ }^{y} \mathrm{PIF}: \mathrm{TPF}=$ the ratio of peak impact force (PIF) to time to peak force (TPF), in newtons per millisecond.

****Significant at $P=0.05$ and 0.01 , respectively.

Susceptibility to bruise damage for any particular fruit depends on the internal tissue structure (Garcia et al., 1988). Peach and nectarine fruits are dense, with a low volume of intracellular air space, and are susceptible to deep bruising. Peach bruises usually develop as internal cone-shaped and radial fractures that may not be visible soon after impact at the fruit surface. Discoloration from some bruises is initiated from as far down as $5 \mathrm{~mm}$ below the fruit surface, and may not be visible externally. More information is needed to explain the physical and physiological attributes that confer peach bruise resistance before bruising thresholds can be obtained for peach cultivars and applied for improving handling procedures in the fresh peach industry.

This study was conducted to evaluate the potential of impact testing as a measure of bruise resistance for four peach cultivars. Various impact variables were measured to investigate the effect of cultivar, ripeness, drop height, and firmness on fruit bruise incidence, bruise volume, respiration, and ethylene evolution rate of freshly harvested peaches. A simple method for assessing peach bruise resistance is discussed.

Peach fruit (cultivars Ranger, Topaz, Glohaven, and Elberta) were hand harvested from trees located at the Oklahoma Fruit Research Station near Perkins, Okla. Peaches were graded into three stages of ripeness, based on fixed $\mathrm{L}$, $\mathrm{a}$, and $\mathrm{b}$ values, by means of tristimulus colormeter (Minolta CR200; Ramsey, N.J.) readings from the greenest portion of the fruit. Ripeness stage 1 and 2 fruit corresponded to the categories threshold-mature (fruit that have just reached physiological maturity and will continue normal ontogenic development after harvest) and mature (fruit that are past the maturity of the fruit in the threshold-mature category but have not undergone significant ripening) (Delwiche and Baumgardner, 1983). Ripeness stage 3 fruit were firm ripe (fruit that had undergone ripening but were still firm; Byrne et al., 1991). The calorimeter was calibrated with a white reference plate $(\mathrm{Y}=93.7$, $\mathrm{x}=0.314, \mathrm{y}=0.321$ ). About 100 sound peaches representing each ripeness stage were transported to the laboratory. Thirty of these fruit were randomly selected for evaluation with an Effegi firmness tester (Effegi, Afolnsine, Italy) equipped with a standard 8-mmdiameter probe. Firmness was measured on opposite cheeks of each peach. The remainder of peaches were used for subsequent im- pact analysis and storage experiments.

The apparatus used for applying and measuring impact loads was the same as that described by Brusewitz et al. (1991). Components of the apparatus consisted of a padded vacuum source to hold each fruit in a selected orientation before release onto the flat, hard surface of the impact force transducer, which was secured to a $20-\mathrm{kg}$ aluminium base. Drop heights were infinitely adjustable from 0 to $50 \mathrm{~cm}$ from the bottom of the fruit. Impact variables measured by the instrumentation were: peak impact force (PIF), time-to-peak force (TPF), contact time (CT), and absorbed energy (AE). Percent absorbed energy (\% AE) was derived as the proportion of total input energy absorbed by the fruit.

Before impact testing, peaches were weighed and pubescence was rubbed off by gently wiping the fruit surface with a cotton cloth to ensure a good seal by the vacuum holder. Fruit were placed under the padded vacuum source and vacuum was adjusted to hold them in place. Peaches were oriented to impact at a site intermediate in color. Drop height $(5,10$, or $15 \mathrm{~cm})$ was adjusted from the bottom of fruit, and a mark was made with a permanent-ink felt pen at the intended impact site. Impact testing was initiated by interrupting the vacuum source and allowing the fruit to fall onto the impact-force transducer. After impact, the fruit bounced up and was caught by hand before impacting a second time. Peaches were stored at $24 \mathrm{C}$ for $24 \mathrm{~h}$ and then cut at the impact site for bruise incidence and dimension measurements. Bruise length (L) and depth (D) were measured from a cut parallel to the stem-calyx axis, and bruise width (W) was measured from a perpendicular cut. Total bruise volume (V) was computed assuming an ellipsoidal cone where: $\mathrm{V}=1.33 \pi \mathrm{LDW} / 8$ (Hung and Prussia, 1989). Bruise incidence was based on whether a bruise was visible at the cut surface of the mesocarp below the impacted area. Impact analysis was conducted using seven peaches from each ripeness class and at each drop height. Data were subjected to analysis of variance, and least significant difference (LSD) tests were employed for mean comparison where $\mathrm{F}$ was significant.

Ethylene and $\mathrm{CO}_{2}$ production was monitored in a subsequent fruit-bruising study. Ethylene and $\mathrm{CO}_{2}$ evolution rates were first determined for 10 fruit from each ripeness class on the day of harvest. Individual fruit were weighed and then sealed in 500-ml jars fitted with rubber gas septa. Duplicate l-ml headspace atmosphere gas samples were taken after $1 \mathrm{~h}$ at $20 \mathrm{C}$ and used for ethylene analysis by gas chromatography and for $\mathrm{CO}_{2}$ analysis by infrared gas analysis (McCollum, 1989). Jars were opened, and fruit were divided into lots of five each; one set was subjected to impact loading (drop height $30 \mathrm{~cm}$ ). Both sets of fruit were then stored in ventilated $500-\mathrm{ml}$ jars at $20 \mathrm{C}$, and ethylene and $\mathrm{CO}_{2}$ evolution rates were determined daily over the next 3 days.

Fruit from the cultivars used in this study differed in mesocarp firmness between certain cultivars, and between all ripeness classes (Table 1). The cultivars that were firm were 'Topaz' and 'Ranger'; intermediate, 'Glohaven'; and least firm, 'Elberta'. The mean firmness values for ripeness classes 1 and 2 correspond generally to the tristimulus colorimeter ripeness categories threshold-mature and mature (Delwiche and Baumgardner, 1983). Ripeness class 3 fruit correspond to the firm-ripe category (Byrne et al., 1991).

The effect of cultivar, ripeness stage, drop height, and fruit mass on various impact forces, bruise incidence, and bruise volume was tested by analysis of variance (Table 2). Significant effects of dependent variables suggested further analysis to determine their relative importance for fruit response to impact and for bruise susceptibility.

Peak impact force increased with increasing fruit mass and drop height (Table 3), as would be expected, since PIF serves as a measure of the maximum velocity and total mass of a falling object. Although fruit mass increased with successive ripeness stages, PIF was not generally affected by degree of ripeness. We expected that fruit firmness would influence PIF by altering the tissue's response to impact: adjacent cells of a lessfirm fruit should slide more easily with respect to each other, cushioning the fruit during impact with a net result of increased CT with the impacted surface (and decreased PIF vs. fruit mass). The data for CT support this assumption. Delwiche's (1987) results for peach fruit were similar. 'Topaz' and 'Glohaven' had the largest mass and exhibited the highest PIF values.

The ratio PIF : TPF was affected within cultivars by drop height and stage of ripeness, but not fruit mass (Table 2). The PIF : TPF variable was strongly related to fruit firmness. By comparison of rankings for fruit firmness by cultivar and over all ripeness 
Table 3. Influence of peach fruit characteristics on their response to various impact forces and bruising.

\begin{tabular}{|c|c|c|c|c|c|c|c|c|c|}
\hline \multirow[b]{2}{*}{$\begin{array}{l}\text { Ripeness } \\
\text { stage }^{y}\end{array}$} & \multirow{2}{*}{$\begin{array}{c}\text { Drop } \\
\text { ht } \\
(\mathrm{cm}) \\
\end{array}$} & \multirow{2}{*}{$\begin{array}{c}\text { Fruit } \\
\text { mass } \\
(\mathrm{g}) \\
\end{array}$} & \multirow[b]{2}{*}{$\operatorname{PIF}^{x}(N)$} & \multirow[b]{2}{*}{$\begin{array}{c}\text { PIF : } \mathrm{TPF}^{\mathrm{w}} \\
(\mathrm{N} / \mathrm{ms})\end{array}$} & \multirow{2}{*}{$\begin{array}{c}\text { Contact } \\
\text { time } \\
(\mathrm{ms})\end{array}$} & \multicolumn{2}{|c|}{ Absorbed energy } & \multirow{2}{*}{$\begin{array}{c}\text { Bruise } \\
\text { incidence } \\
(\%)\end{array}$} & \multirow[b]{2}{*}{$\begin{array}{c}\text { Bruise } \text { vol }^{w} \\
\left(\mathrm{~cm}^{3}\right)\end{array}$} \\
\hline & & & & & & $\begin{array}{c}\text { Total } \\
(\mathrm{J} \times 103) \\
\end{array}$ & $\begin{array}{l}\text { Propor- } \\
\text { tional (\%) }\end{array}$ & & \\
\hline & & & & & Ranger & & & & \\
\hline \multirow[t]{3}{*}{1} & 5 & $114(30)$ & $108(16) \mathrm{c}^{u}$ & $67(11) \mathrm{c}$ & $3.5(0.6) \mathrm{a}$ & $31 \quad(8) c$ & $55(3) \mathrm{b}$ & $0 \mathrm{a}$ & 0 \\
\hline & 10 & $126(30)$ & 159 (9) b & $96(14) b$ & $3.7(0.7) \mathrm{a}$ & $75(22) b$ & $60(5) a$ & $14 \mathrm{a}$ & $0.02(0.05) \mathrm{a}$ \\
\hline & 15 & $130(27)$ & 203 (24) a & $125(18) \mathrm{a}$ & $3.7(0.5) \mathrm{a}$ & $120(28) \mathrm{a}$ & $61(4) a$ & $14 \mathrm{a}$ & $0.04(0.10) \mathrm{a}$ \\
\hline \multirow[t]{3}{*}{2} & 5 & $125(27)$ & $96 \quad(7) c$ & $49 \quad(7) c$ & $4.4(0.7)$ a & $35 \quad(9) c$ & 57 (4) b & $0 \mathrm{a}$ & $\begin{array}{ll}0 & a\end{array}$ \\
\hline & 10 & $128(24)$ & $148(15) \mathrm{b}$ & $82(11) b$ & $4.0(0.6) \mathrm{ab}$ & 78 (18) b & $62(5) \mathrm{a}$ & $0 \mathrm{a}$ & $\begin{array}{ll}0 & a\end{array}$ \\
\hline & 15 & $136(33)$ & $205(30) \mathrm{a}$ & $122(10) \mathrm{a}$ & $3.7(0.4) b$ & $130(32) \mathrm{a}$ & $63(2) \mathrm{a}$ & $14 \mathrm{a}$ & $0.04(0.09) \mathrm{a}$ \\
\hline \multirow[t]{6}{*}{3} & 5 & $164(45)$ & $98(19) \mathrm{c}$ & $40 \quad(6) c$ & $5.5(0.7) \mathrm{a}$ & $50(13) \mathrm{c}$ & $62(3) b$ & $0 \mathrm{a}$ & \\
\hline & 10 & $138(49)$ & $124(34) \mathrm{b}$ & $61(21) b$ & $5.0(1.3) \mathrm{ab}$ & $96(36) \mathrm{b}$ & $71(9) \mathrm{a}$ & $14 \mathrm{a}$ & $0.4 \mathrm{P}(1.0) \mathrm{a}^{\mathrm{a}}$ \\
\hline & 15 & $132(10)$ & $176(26) \mathrm{a}$ & $90 \quad$ (9) a & $\begin{array}{l}4.5(0.8) \mathrm{b} \\
\text { Topaz }\end{array}$ & $150(51) \mathrm{a}$ & $71(5) a$ & $0 \mathrm{a}$ & $\begin{array}{ll}0 & \mathrm{a}\end{array}$ \\
\hline & 5 & 119 (19) & $119(12) \mathrm{c}$ & $78(12) b$ & $3.3(0.4) \mathrm{a}$ & $31 \quad(6) c$ & $53(8) \mathrm{b}$ & $14 \mathrm{~b}$ & $0.02(0.05) \mathrm{b}$ \\
\hline & 10 & $136(10)$ & $191(22) b$ & $129(29) \mathrm{a}$ & $3.4(0.4) \mathrm{a}$ & 78 (9) b & $58(6) \mathrm{ab}$ & $28 \mathrm{~b}$ & $0.11(0.18) b$ \\
\hline & 15 & $145(45)$ & 226 (13) a & 153 (18) a & $3.3(0.3) \mathrm{a}$ & 130 (16) a & $65(5) \mathrm{a}$ & $100 \mathrm{a}$ & $0.42(0.17) \mathrm{a}$ \\
\hline \multirow[t]{3}{*}{2} & 5 & $185 \quad(9)$ & $138(11) \mathrm{c}$ & $66 \quad(7) c$ & $4.6(0.2) \mathrm{a}$ & $49(4) c$ & $54(4) c$ & $0 \mathrm{~b}$ & $\begin{array}{ll}0 & b\end{array}$ \\
\hline & 10 & $190 \quad(8)$ & $213(11) b$ & 113 (12) b & $4.2(0.3) \mathrm{b}$ & 110 (7) $b$ & $60(2) b$ & $0 \mathrm{~b}$ & $\begin{array}{ll}0 & b\end{array}$ \\
\hline & 15 & $189(16)$ & $271(22) \mathrm{a}$ & $158(24) \mathrm{a}$ & $3.9(0.2) \mathrm{c}$ & $190(24) \mathrm{a}$ & 68 (4) a & $71 \mathrm{a}$ & $0.21(0.18) a$ \\
\hline \multirow[t]{6}{*}{3} & 5 & 247 (13) & 150 (4) c & $60 \quad(3) c$ & $5.4(0.2)$ a & $76 \quad(6) c$ & $63(3) b$ & $0 \mathrm{~b}$ & $\begin{array}{lll}0 & a\end{array}$ \\
\hline & 10 & $266(21)$ & $229(16) \mathrm{b}$ & $96(12) b$ & $5.4(0.4)$ a & $170(21) b$ & 67 (4) ab & $0 \mathrm{~b}$ & $\begin{array}{ll}0 & \mathbf{a}\end{array}$ \\
\hline & 15 & $240(67)$ & $284(33) \mathrm{a}$ & $142(21) \mathrm{a}$ & $\begin{array}{l}4.6(0.8) \mathrm{b} \\
\text { Glohaven }\end{array}$ & $250(83) \mathrm{a}$ & $68(5) \mathrm{a}$ & $43 \mathrm{a}$ & $0.54 \quad(.09) \mathrm{a}$ \\
\hline & 5 & $158(58)$ & $121(18) \mathrm{c}$ & $61(10) \mathrm{c}$ & $4.3(0.8)$ a & $42(20) c$ & $53(5) b$ & $0 \mathrm{a}$ & 0 \\
\hline & 10 & $155(60)$ & 173 (22) b & 95 (12) b & $4.1(1.0) \mathrm{a}$ & $96(45) \mathrm{b}$ & $61(6) a$ & $0 \mathrm{a}$ & 0 \\
\hline & 15 & $162(42)$ & $244(37) \mathrm{a}$ & $150(23) \mathrm{a}$ & $3.7(0.6) \mathrm{b}$ & $150(37) \mathrm{a}$ & $63(3) a$ & $0 \mathrm{a}$ & 8 \\
\hline \multirow[t]{3}{*}{2} & 5 & $157(31)$ & $116 \quad(7) c$ & $57 \quad(5) c$ & $4.5(0.6) \mathrm{a}$ & $44 \quad(8) \mathrm{c}$ & $58(3) \mathrm{t}$ & $0 \mathrm{a}$ & 8 \\
\hline & 10 & $179(36)$ & 178 (16) b & 86 (8) b & $4.6(0.6) \mathrm{a}$ & $110(30) \mathrm{b}$ & $64(6) \mathrm{a}$ & $0 \mathrm{a}$ & $\begin{array}{ll}0 & \mathbf{a}\end{array}$ \\
\hline & 15 & $168(50)$ & $226(36) \mathrm{a}$ & 122 (13) a & $4.1(0.6) \mathrm{b}$ & $170(49) \mathrm{a}$ & 67 (3) a & $28 \mathrm{a}$ & $0.21(0.33) \mathrm{a}$ \\
\hline \multirow[t]{6}{*}{3} & 5 & $181(31)$ & 119 (16) c & $52 \quad(6) c$ & $5.0(0.4) \mathrm{a}$ & $52 \quad(6) \mathrm{c}$ & 59 (4) b & $0 \mathrm{a}$ & 0 \\
\hline & 10 & $186(22)$ & 179 (16) b & $84(12) b$ & $4.9(0.4) a b$ & $120(22) b$ & $64(6) a b$ & $14 \mathrm{a}$ & $0.6 .(0.65) a$ \\
\hline & 15 & $201(31)$ & $245(28) \mathrm{a}$ & $122(21) \mathrm{a}$ & $\begin{array}{l}4.5(0.6) \mathrm{b} \\
\text { Elberta }\end{array}$ & $200(40) \mathrm{a}$ & $68(6) \mathrm{a}$ & $0 \mathrm{a}$ & $\begin{array}{ll}0 & \mathrm{a}\end{array}$ \\
\hline & 5 & $142(14)$ & $108(10) \mathrm{c}$ & $53 \quad(8) c$ & $4.4(0.4)$ a & $42 \quad(6) c$ & $60(4) b$ & $0 \mathrm{a}$ & 0 \\
\hline & 10 & $149(9)$ & $157(13) \mathrm{b}$ & $80(10) b$ & $4.4(0.3) \mathrm{a}$ & 96 (8) b & 66 (4) a & $0 \mathrm{a}$ & 0 \\
\hline & 15 & $138(14)$ & $189(24) \mathrm{a}$ & $104(17) \mathrm{a}$ & $4.2(0.2) \mathrm{a}$ & 140 (15) a & 69 (3) a & $0 \mathrm{a}$ & 0 \\
\hline \multirow[t]{3}{*}{2} & 5 & $155(28)$ & $104(15) \mathrm{c}$ & $47 \quad(7) c$ & $4.9(0.4) \mathrm{a}$ & $49 \quad(8) c$ & 65 (3) b & $0 \mathrm{~b}$ & $\begin{array}{ll}0 & \mathrm{a}\end{array}$ \\
\hline & 10 & $169(10)$ & 160 (19) b & 76 (17) b & $4.9(0.7) \mathrm{a}$ & $110(12) b$ & $68(5) a b$ & $43 \mathrm{a}$ & $0.190(0.30) \mathrm{a}$ \\
\hline & 15 & $161(24)$ & 193 (16) a & $95 \quad$ (8) a & $4.7(0.4) \mathrm{a}$ & $170(28)$ a & 71 (4) a & $0 \mathrm{~b}$ & $\begin{array}{ll}0 & a\end{array}$ \\
\hline \multirow[t]{3}{*}{3} & 5 & $162(25)$ & 84 (12) b & 32 (4) b & $6.1(0.3) \mathrm{a}$ & 58 (9) a & 73 (3) a & $14 \mathrm{~b}$ & $0.05(0.12) b$ \\
\hline & 10 & $154(27)$ & $150(24) \mathrm{a}$ & 73 (16) a & $4.7(0.7) b$ & $100(22) \mathrm{b}$ & $68(5) b$ & $0 \mathrm{~b}$ & $\begin{array}{ll}0 & b\end{array}$ \\
\hline & 15 & $185(50)$ & $168(31) \mathrm{a}$ & 66 (16) a & $6.0(0.8) \mathrm{a}$ & $210(59)$ a & 77 (4) a & $71 \mathrm{a}$ & $0.74(0.67) \mathrm{a}$ \\
\hline
\end{tabular}

${ }^{2}$ All data are presented as means of seven measurements, SD are presented in parentheses.

${ }^{y}$ Ripeness stages were determined based on fixed $\mathrm{L}$ a, and $\mathrm{b}$ values obtained from the greenest area of peaches: $1=$ threshold-mature, $2=$ mature, $3=$ firm ripe.

${ }^{x}$ Peak impact force.

"PIF : TPF $=$ the ratio of peak impact force (PIF) to time to peak force (TPF), in newtons per millisecond.

"In cases where bruise incidence $<100 \%$, some zero bruise volumes were included for computation of means.

"Mean separation within columns between drop heights by LSD, $P=0.05$.

stages, the results for firmness indicate the same general order as PIF : TPF, with slightly different grouping of cultivars into firmness classes. Both methods ranked 'Topaz', 'Ranger', 'Glohaven', and 'Elberta' in order of most to least firm, respectively. Effegi results grouped 'Topaz' and 'Ranger' as most firm, 'Glohaven' as intermediate, and 'Elberta' as least firm (Table 1). PIF : TPF results grouped the cultivars slightly differently, with 'Topaz' most firm, 'Ranger' and 'Glohaven' intermediate, and 'Elberta' least firm. The PIF : TPF variable has been used to serve as the major criterion for automated peach firmness sorting (Delwiche et al., 1989).

The total absorbed energy at impact (AE) increased with drop height and stage of ripeness (Table 3). Standard deviations for AE increased with stage of ripeness, indicating that the energy absorbed at impact for riper fruit was more variable than that for lessripe fruit, perhaps dependent on slightly dif- ferent mesocarp structure. The increased variability may have resulted from different mechanisms of internal tissue failure, dependent on the level of mesocarp softening. Some differences between cultivars may also be explained by differences in fruit size. 'Ranger' appeared to absorb less total energy on impact than the other three cultivars, but 'Ranger' fruit were also noticeably smaller. The variability in $\mathrm{AE}$ estimates can be reduced by expressing energy absorbed during impact as a percentage of the input energy (\%AE; Brusewitz et al., 1991). The \%AE values did not increase in variability appreciably with increasing stage of ripeness. Between cultivars, there was a consistent ordering of \% AE into two groups: 'Elberta' fruit absorbed a higher percentage of total input energy than 'Ranger', 'Topaz', or 'Glohaven' fruit.

Average bruise volumes increased with drop height and especially with stage of ripeness (Table 3). Although these differences were large, they were not always statistically significant due to high SDS (in many cases, SDS exceeded means). We suspect the cause for this variability was the absence of bruises in many cases at the chosen drop heights. The magnitude of the inherent errors encountered in computing bruise volume for determining bruise resistance of peach fruit caused us to search for a simpler measure of bruise resistance. A regression analysis between bruise incidence (percentage of fruit bruised) and average bruise volume for fruit at similar ripeness stages resulted in a positive correlation coefficient of 0.86 . This high correlation suggests that simple visual inspection for mesocarp bruising below the point of impact can substitute for the tedious measurement of bruise volume for comparing impacted fruit of the same degree of ripeness, when exposed to impact energies similar to those used here.

Many researchers have found that absorbed energy at impact is strongly related, 
often linearly, to bruise volume for apple (Malus domestica Borkh.) fruit (Brusewitz and Bartsch, 1989; Diener et al., 1979; Schulte-Pason et al., 1990). We found that the correlation between bruise volume and absorbed energy at impact for peaches was very weak $\left(r^{2}=0.17\right)$ for the four cultivars studied. Hung and Prussia (1989) used impact energies varying from 0.155 to $1.003 \mathrm{~J}$ and found that the percentage of bruised 'Red Globe' peaches ranged from $10 \%(0.155 \mathrm{~J})$ to $90 \%(1.003 \mathrm{~J})$. Where their impact energies overlapped ours (0.06 to $0.32 \mathrm{~J}$ ) the results were similar. In most cases where impact energy was $10.155 \mathrm{~J}$, the bruised fruit we observed ranged between $14 \%$ and $20 \%$ (Table 3 ). In a comparison of the mechanical properties of apples, pears ( Pyrus communis L.), apricots ( Prunus armeniaca L.), and peaches, Fridley and Adrian (1966) concluded that peach fruit were most resistant to impact bruising. We used relatively low energies to study impact bruising of peaches. Application of greater impact energy (higher drop heights) to the fruit in our study likely would have resulted in a higher percentage of bruised fruit and increased the confidence for identifying differences in bruise resistance among the cultivars studied.

Fruit impact, under the conditions of this study, had little to no effect on respiration or ethylene evolution. Doubling the drop height from 15 to $30 \mathrm{~cm}$ theoretically should increase the impact energy by $\approx 41 \%$ (input energy is proportional to the square root of drop height; Mohsenin, 1970). This change would increase input energies to a minimum of 0.295 ('Ranger', ripeness stage 1) and a maximum of $0.60 \mathrm{~J}$ ('Topaz' at ripeness stage 3 ), approaching the moderate impact energy level used by Hung and Prussia (1989) in which $\approx 50 \%$ of 'Red Globe' peaches bruised.

We have evaluated various physical variables derived from a fruit impact test at relatively low-impact energy. Under these conditions, no single variable was highly correlated with the incidence or severity of bruising. Use of higher-impact energies likely would increace the incidence of bruising and decrease the observed variability in bruise measurements. A simple assessment procedure for bruise resistance should include exposure of fruit to equal impact energies, allow sufficient time for bruise discoloration development under controlled conditions, and provide a sensitive measure of bruise severity. Our results indicate that impact energies should be applied at a sufficiently high level to consistently induce bruising in at least the more-susceptible cultivars under study. When comparing fruit at similar ripeness stages, our data indicate that bruise incidence (observed in the mesocarp directly below the location of impact) may substitute for bruise volume as a rapid qualitative measure of bruise susceptibility. Bruise dimension measurements may still be necessary for comparing bruise sevœrity between fruit of differing ripeness anid or bruise susceptibilities. Since peach cultivars differ in fruit mass, peach fruit bruise :susceptibility may be better tested bv exposure of fruit to one standard impact energy by dropping a mass onto the fruit, rather than dropping the fruit onto a surface.

\section{Literature Cited}

Bilanski, W.P and D.R. Menzies. 1984. Bruising related to mechanical harvesting of apples and peaches. Proc. Intl. Symp. Fruit, Nut and Veg. Harvesting Mechanizations, SPS-84:376381; Amer. Soc. Agr. Eng., St. Joseph, Mich. Brown. G.K., N.L. Schulte-Paxon. and E.J. Timm. 1990. Impact classification using the instrumented sphere. ASAE Paper no. 90-6001, Amer. Soc. Agr. Eng., St. Joseph, Mich.

Brusewitz, G.H. and J.A. Bartsch. 1989. Impact parameters related to postharvest bruising of apples. Trans. Amer. Soc. Agr. Eng. 32:953-957.

Brusewitz, G.H., T.G. McCollum, and X. Zhang. 1991. Impact bruise resistance of peaches. Trans. Amer. Soc. Agr. Eng. 34:962-965.
Byrne, D.H., A.N. Nikolic, and E.E. Burns. 1991. Variability in sugars, acids, firmness, and color characteristics of 12 peach genotypes. J. Amer. Soc. Hort. Sci. 116:1004-1006.

Delwiche, M.J. 1987. Theory of fruit firmness sorting- by impact forces. Trans. Amer. Soc. Agr. Eng. 30:1160-1166. 1171.

Delwiche, M.J. and R.A. Baumgardner. 1983. Ground color measurements of peach. J. Amer. Soc. Hort. Sci. 108:1012-1016.

Delwiche, M.J., S. Tang, and J.J. Mehlschau. 1989. An impact force response fruit firmness tester. Trans. Amer. Soc. Agr. Eng. 32:321326.

Diener, R.G., K.C. Elliott, P.E. Nesselroad, M. Inele. R.E. Adams. and S.H. Blizzard. 1979. Bruise energy of peaches and apples. Trans. Amer. Soc. Agr. Eng. 22:287-290.

Fridley, R.B. and P.A. Adrian. 1966. Mechanical properties of peaches, pears, apricots and apples. Trans. Amer. Soc. Agr. Eng. 9:135-142.

Garcia, C., M. Ruiz, and P. Chen. 1988. Impact parameters related-to bruising in selected fruits. ASAE Paper no. 88-6027. Amer. Soc. Agr. Eng., St. Joseph, Mich.

Hung, Y.C. and S.E. Prussia. 1989. Effect of maturiy and storage time on the bruise susceptibility of peaches (cv. Red Globe). Trans. Amer. Soc. Agr. Eng. 32:1377-1382.

McCollum, T.G. 1989. Physiological changes in yellow summer squash at chilling and nonchilling temperatures. HortScience 24:633-635.

Mohsenin, N.N. 1970. Physical properties of plant and animal materials. vol. I. Gordon and Breach, New York. p 401-430.

Sargent, S.A., J.K. Brecht, and J.J. Zoellner. 1990. Analysis of tomato and bell pepper packing lines using the instrumented sphere. ASAE paper no. 90-6024, Amer. Soc. Agr. Eng., St. Joseph, Mich.

Schulte-Pason, N.L., E.J. Timm, and G.K. Brown. 1990. Apple, peach and pear impact damage thresholds. ASAE Paper no. 90-6002, Amer. Soc. Agr. Eng., St. Joseph, Mich.

Zapp, H.H., S.H. Ehlert, G.K. Brown, P.R. Armstrong. and S.S. Sober. 1990. Advanced instrumentation sphere (IS) for impact measurements. Trans. Amer. Soc. Agr. Eng. 33:955960. 